\title{
Occurrence of Cytomegalo Virus and Herpes Simplex Virus Infections in Pregnancy
}

Dear editor,

Both cytomegalovirus (CMV) and herpes simplex virus (HSV) are known to have an intrauterine route of transmission with significant mortality and morbidity. ${ }^{[1]}$ Primary CMV infection in pregnancy causes a higher incidence of congenital malformations and fetal loss. ${ }^{[2]}$ The virus can be transmitted in utero with both primary and reactivated maternal infections but these reactivated maternal infections seldom result in fetal damage. ${ }^{[3]} \mathrm{HSV}$ infection of the female genital tract is known to be primary as well as recurrent. ${ }^{[4]}$ Primary maternal infection appears to be of greatest risk to the fetus, both early in pregnancy and at term. ${ }^{[5]}$ Spontaneous reactivation occurs in spite of HSV-specific immunity in the host. However, immunity limits local viral replication so that recurrent infections are less extensive and less severe. ${ }^{[3]}$ Maternal infections with adverse outcome are initially inapparent or asymptomatic and thus, difficult to diagnose on clinical grounds. Their diagnosis is usually established by seroconversion in paired sera or by the presence of specific IgM. A total of 200 pregnant women were investigated including 150 women with bad obstetric history $(\mathrm{BOH})$ and 50 control women with normal obstetric history for CMV and HSV infections from October 2004 to February 2006. All the patients were in the age range of 16-41 years. Blood samples were collected, sera were separated and IgM antibodies against CMV and HSV were detected using CMV IgM enzyme linked immunosorbent assay (ELISA) and HSV-1 and -2 IgM ELISA kit (Diagnostic system laboratory) following 


\begin{tabular}{|c|c|c|c|}
\hline \multicolumn{4}{|c|}{$\begin{array}{l}\text { Table: Seroprevalence of IgM antibodies against CMV } \\
\text { and HSV in pregnant women with bad obstetric history }\end{array}$} \\
\hline $\begin{array}{l}\text { Obstetric } \\
\text { history }\end{array}$ & $\begin{array}{c}\text { Number } \\
\text { of women } \\
\text { tested }\end{array}$ & $\begin{array}{c}\text { No. }(\%) \\
\text { of CMV } \\
\text { IgM }\end{array}$ & $\begin{array}{c}\text { No. }(\%) \\
\text { of HSV } \\
\text { IgM }\end{array}$ \\
\hline $\mathrm{BOH}$ & 150 & $7(4.67)$ & $5(3.33)$ \\
\hline $\begin{array}{l}\text { Recurrent } \\
\text { abortions }\end{array}$ & 150 & $3(2.00)$ & $4 \quad(2.67)$ \\
\hline $\begin{array}{l}\text { Congenital } \\
\text { malformation }\end{array}$ & 14 & $2(14.28)$ & - \\
\hline $\begin{array}{l}\text { Intrauterine } \\
\text { death (IUD) }\end{array}$ & 13 & $1(7.69)$ & - \\
\hline Preterm delivery & 12 & $1(8.33)$ & $1(8.33)$ \\
\hline
\end{tabular}

the manufacturers' instructions. The results were interpreted as being seropositive if the optical density (OD) value of the sample was more than that of the cut-off value. Only seropositive cases were tested for IgG antibodies against CMV and HSV. CMV IgG was tested by using the ELFA (Enzyme linked fluorescent assay) technique and the HSV IgG was tested by using the ELISA technique.

All seropositive cases were in the age group of 22-30 years and were asymptomatic. Seropositivity for CMV and $\mathrm{HSV}$ in $\mathrm{BOH}$ cases is shown in the table. The difference in seropositivity of $\mathrm{CMV}$ between $\mathrm{BOH}$ and control cases was statistically significant $(P<0.05)$ and for HSV was statistically insignificant $(P>0.05)$. These findings were consistent with earlier studies. ${ }^{[1,2,4]}$ Out of seven CMV seropositive cases, five cases were positive for both $\mathrm{IgG}$ and $\operatorname{IgM}$ and the remaining two were positive for $\operatorname{IgM}$ only. Out of five HSV IgM seropositive cases, three were positive for IgG and IgM and the remaining two were positive for IgM only. IgG seropositivity has also been demonstrated in a previous study. ${ }^{[2]}$ The present study demonstrates the association of these infections with various obstetric losses which is comparable to the observations by other authors. ${ }^{[2,4]}$ Fetal outcome was studied in seropositive cases.
One CMV-seropositive case had a male child with jaundice, hepatosplenomegaly and purpura. All other seropositive cases had full-term, normal delivery (FTND) of clinically normal children. Among HSV-seropositive cases, one showed preterm delivery and all others had FTND of clinically normal children.

Thus, it is concluded that CMV and HSV infections are responsible for some obstetrical losses. Unfortunately, there is no vaccine for prevention and there is no way to prevent fetuses from becoming infected once the mother acquires the infection. It is suggested that women in the reproductive age group should be screened for CMV and HSV infections especially in a developing country like India along with preexisting antenatal screening for HIV and syphilis.

\section{References}

1. Surpam RB, Kmlakar UP, Khadse RK, Qazi MS, Jalgaonkar SV. Serological study for TORCH infection in women with bad obstetric history. J Obstet Gynaecol India 2006;56:41-3.

2. Turbadkar D, Mathur M, Rele M. Seroprevalence of TORCH infection in bad obstetric history. Indian J Med Microbiol 2003;21:108-10.

3. Jawetz E, Melnick JL, Adelberg EA, Brooks GF. Herpesviruses Chapter 33. In: Jawetz, Melnick and Adelberg medical microbiology. $23^{\text {rd }}$ ed. USA: Lange Medical Books/ Mcgrawhill; 2004. p. 443,435.

4. Mookherjee N, Gogate N. Incidence of HSV infection in bad obstetric history cases. Indian J Med Microbiol 1994;12:60-4.

5. Stagno S, Whitley RJ. Herpesvirus infection of pregnancy, Part II: Herpes simplex virus and varcella zoster virus infections. N Engl J Med 1985;313:1327-9.

\section{S Gumber, *U Arora, P Devi}

Department of Microbiology, Government Medical College, Amritsar - 143 001, Punjab, India

*Corresponding author (email: <ushar_ora@yahoo.co.in>)

Received: 17-01-07

Accepted: 26-07-07 